\title{
6 \\ Regional and Non-regional Cults of Affliction in Western Zambia ${ }^{1}$ by Wim M.J. Van Binsbergen
}

\begin{abstract}
1. Introduction
A generic relation holds between two types of cult of affliction in Zambia's Western Province (formerly Barotseland). Cults of one type, the non-regional, form a substratum out of which cults of the other type, the regional, may spring forth under certain conditions, and into which they submerge again under different conditions. To understand this process and the conditions that govern it, I shall first describe the non-regional cults of affliction and then define the general characteristics by which the others set themselves apart from the substratum. Finally, I shall compare in some detail the development of two regional cults in order to make clear the importance of two series of variables: each distinct cult's characteristics of idiom and internal organizational structure, and the structural characteristics of the geographical area which the cult transforms into a cultic region.
\end{abstract}

Several working definitions are useful in order to establish the contrast, briefly, between the types of cult within the general class of cults of affliction. The first type covers a few regional cults which have three main

1 This paper is based on my research into Central African religious change, in which I have been engaged since 1971. Fieldwork was undertaken alternatingly in Lusaka and Kaoma district, Western Province, Zambia, during 27 months, from February 1972 to April 1974. Of this period, rural research was carried out in February 1973, May-June 1973 and August-April 1974. Research both in Lusaka and Kaoma district concentrated on the Nkoya ethnic group but in addition involved religious and political organizations of a much wider scope. A research grant from the Uious and of Zambia covered initial research expenses in the period grant from the University 1973-74 I was a Research Affiliate of the Univerity period February-April 1972. In Studies, in which capacity I benefited from its of Zambia's Institute for African Netherlands Foundation for the Advancem its various research facilities. The provided a writing-up grant the Advancement of Tropical Research (WOTRO) provided a writing-up grant for the period 1974-75. The University of Leiden paid Whild my participation in the 1976 ASA conference, which led to the present paper. While registering my indebtedness and gratitude vis-a-vis these various instutitions, the Zambian authorities and my informants, I wish to thank in particular the following people: Denes Shiyowe for excellent research assistance; in particular the my wife, for sharing much of the fieldcerk Andre Kobben, Maud Munteman, Schoffeleers, Jaap Van Velsen,emba, Bob Papstein, Terry Ranger, Mathew comments and discuss Velsen, and Richard Werbner who over the years through Comments and discussions, have contributed to my analysis; and finally Richard Werbner for his most stimulating editorial efforts towards the production of the
present paper. 
characteristics. Each of these regional cults has a specific idiom of its own. This idiom is pursued by a number of local congregations spread over an area of thousands of square kilometres. Thirdly, and most importantly, an interlocal formal organization binds these dispersed congregations through the interactions of the cult's officials. In this way the geographical area over which the cult spreads is transformed into a region. What structures a cult's region is thus the processes of interlocal communication, interaction and distribution which the cult gives rise to. By contrast, the second type covers cults which I shall call non-regional. A cult of this type, too, has a specific cult idiom which is pursued by a number of congregations. However, although it may have spread over a vast area, it has not yet transformed the area into a region of its own, or it has ceased to do so and a former region has become merely a non-regional area.

As for the general class of cults of affliction, in terms of cult idiom individual affliction invariably stands out as a major concern. This is central in Turner's classic studies $(1957 ; 1962 ; 1968)$ and in the earlier works (Kuntz 1932; White 1949; Gluckman 1943, 1951; McCulloch 1951: 72f; Turner 1952) which he developed. Turner coined the phrase, 'cult of affliction', to denote a cult (religious subsystem) characterised by two elements: (a) the cultural interpretation of misfortune (bodily disorders, bad luck) in terms of exceptionally strong domination by a specific non-human agent; (b) the attempt to remove the misfortune by having the afflicted join the cult venerating that specific agent. The major ritual forms of this class of cults consist of divinatory ritual in order to identify the agent, and initiation ritual through which the agent's domination of the afflicted is emphatically recognised before an audience. In the standard local interpretation, the invisible agent inflicts misfortune as a manifest sign of his hitherto hidden relationship with the afflicted. The purpose of the ritual is to acknowledge the agent's presence and to pay him formal respect (by such conventional means as drumming, singing, clapping of hands, offering of beer, beads, white cloth and money). After this the misfortune is supposed to cease. The afflicted lives on as a member of that agent's specific cult; he participates in cult sessions to reinforce his good relations with the agent and to assist others, similarly afflicted, to be initiated into the same cult.

Cults of affliction represent a dominant class of cults in present-day Western Zambia. However, in addition there are ancestral cults, individual specialists' cults, chiefly cults and various types of Christian cults. ${ }^{2}$ Of these, Christian cults and the major chiefly cults are regional (Van Binsbergen 1976d, 1977a).

2 Christian churches are cults in terms of my definition of cult. However, they would be distinguished from cults in the dominant sociological approach to types of religious organization, which has been developed on the basis of the writings of religious organization, which has been developed on the basis of the
Troeltsch, Von Wiese, Becker, and Yinger (cf. Kolb 1964; O'Dea 1968).

142

\section{Non-Regional Cults of Affliction}

\subsection{Main Characteristics}

Non-regional cults of affliction occur in scores of versions throughout Western Zambia and surrounding areas (Carter 1972; Van Binsbergen 1972b, 1976d). These various cults have much in common. They differ from each other mainly in the following respects: the associated paraphernalia (e.g. type of adept's shrine, musical instruments, vegetal medicine, ritual objects and bodily adornment used); the specific misfortunes for which each cult caters; and the name and alleged nature of the invisible agent venerated in each cult. Each cult is locally known by the name of this specific agent. Some particularly successful cults are encountered over large areas and are mentioned repeatedly in the literature; these include such cults as mayimbwe, muba, songo, viyaya, liyala and bindele.

We are indebted to Turner for his masterly description and analysis of some cults of affliction among the Ndembu. He shows the role of these cults in the succession of "social dramas" that make up the micro-history of villages over a time-span of several decades. However, he does not analyse the historical dimension of these cults themselves (cf. Shorter 1972: 141). In Turner's work these cults are viewed as given institutions that are manipulated within the local social process, rather than as the dynamic outcomes of a process of religious change that in itself needs elucidation.

White $(1949,1961)$ was the first to explore the cults' historical dimension. $\mathrm{He}$ pointed to a major conceptual shift that has affected cults of affliction in Luvale country, since the 1930's. The shift was away from cults that claimed local ancestors (particularly diviners and hunters) as their afflicting agents. It was towards new cults that attributed affliction to abstract, scarcely personalized agents whose names were reminiscent of contacts with distant alien groups, African and European. Some of these new cults were songo (after the Songo people of Angola), ndeke (airplane), bindele (white people or people clad in white: either Europeans or alien African traders). Turner's (1957: 296f) and my own fieldwork suggest, moreover, that the conceptual shift was accompanied by a shift in the recruitment pattern of the cults' congregations. This structural shift was from a ritual congregation that was rather coterminous with the local community and that focussed on communal symbols (village shrine, ancestors), to a congregation whose members, individually drawn from a series of adjacent local communities, would associate for ad hoc ritual purposes in a pattern that cuts across, rather than reinforces the structure of distinct local communities. However, as I shall show, in contrast to Turner's observations, my data point to the significance of local factors in the cults (see below, 2.4).

White suggested that the conceptual shift may be attributed to a complex of interrelated changes. These included increased interlocal contacts (through 19th century long-distance trade and 20th century labour migration), the 
breakdown of the village community, and the emergence of new causal models for the interpretation of misfortune. White interpreted these new models (featuring new, impersonal, non-ancestral affliction agents) as the conceptual response to the widening of the social horizon beyond the area where the ancestors could be thought to hold sway.

Elsewhere I have developed White's stimulating ideas in the light of more comprehensive data on religious change in this part of Central Africa (Van Binsbergen 1976d). There I argue that the emergence of these non-regional cults of affliction represents just one specific outcome in an overall process of religious transformation. This process has extended over centuries and, as other outcomes, has produced such religious forms as chiefly cults, prophetism concentrating on "ecological" concern for the land and its produce, eschatological prophetism, and sorcery eradication movements. Throughout a succession of emerging religious forms, the overall process produced systematic changes in religious idiom. These changes can be conveniently mapped along five dimensions: the perception of time; the degree of "ecological" concern; conceptions concerning the nature of supernatural beings; the degree of individual-centredness; and the interpretation of evil. Ultimately, major political and economic changes can be seen as the motor behind the overall religious transformation. In this context I am thinking primarily of the increase of interlocal structures of political and economic power, distribution, and movement of people due to precolonial and colonial state-formation, raiding, long distance trade, and labour migration. These extra-religious changes called for new religious forms (including non-regional cults of affliction) that were capable of legitimating the new structures and that could meet the existential and interpretative needs of the people involved.

My field data mainly derive from the Nkoya, an ethnic group inhabiting the wooded plateau of central Western Zambia (Clay 1945; McCulloch 1951; Symon 1959; Van Binsbergen 1975, 1976a, 1976b, 1976c). Among the Nkoya, ancestral cults of affliction have continued to exist until today, but the great majority of affliction cases is now treated within the more recent, non-ancestral cults, particularly those of the non-regional type to which the present section is devoted. People recognize the recent nature of these cults, and can state the period in which a particular cult first reached their area The non-ancestral, non-regional cults of affliction spread like fashions or epidemics. For many cults occurring in an area it is known from which direction they arrived; they became locally associated with ethnic groups living in that direction, and are sometimes held, incorrectly, to represent those groups' ancestral ritual. ${ }^{3}$. Intervals of a few years would pass between a new cult's arrival and its being forced out of fashion by the arrival of yet another one. As an area is hit by a succession of cult fashions, many people come to be initiated into more than one cult. As a fashion wears out, the ritual for that cult will be staged less frequently and fresh cases of affliction will be attributed mainly to more recently arrived cults.
Map 1: Ethnic Groups and Localities in Western Zambia

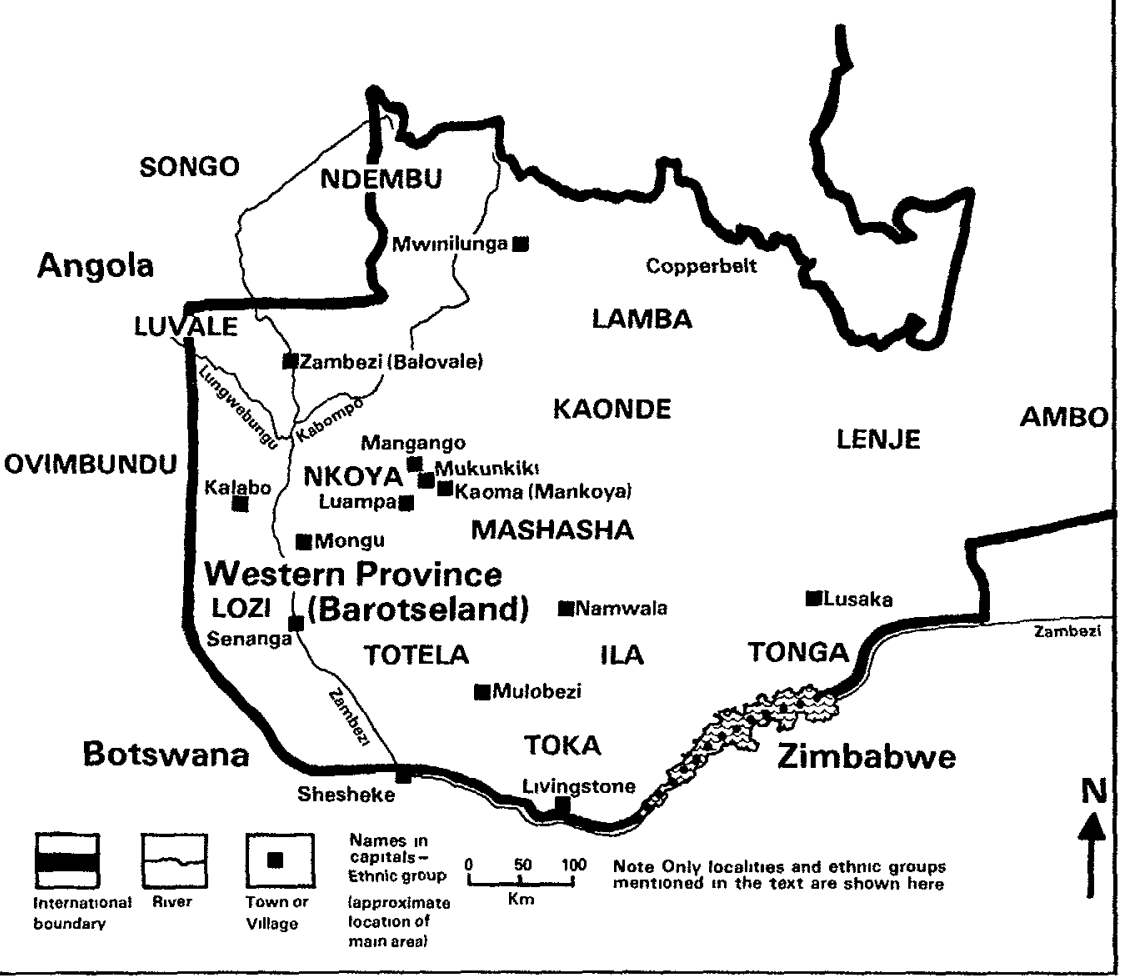

However, cult leaders keep staging the rituals of non-ancestral cults of somewhat older vintage. In this way they revive their ritual links with adepts whom they initiated some years before and who may since have taken not only to other cults but also to other leaders.

3 The following associations between non-regional cults of affliction and ethnic groups are recognized in Western Zambia: the songo cult is associated with the Songo people of Angola (McCulloch 1951), and introduced in Western Zambia by the Luvale (Ikacana 1971), chimbandu with the Angolan Ovimbundu (McCulloch 1951): kayongo with the Luvale (Kuntz 1932) or in general with Angolan immigrants the Luvale (Ikacana 1971, my fieldnotes); liyala with the Lozi (Kuntz 1932; Gluckman 1951); macoba with the Kaonde (Kuntz 1932); mayimbwe with the Nkoya (Kuntz 1932; Gluckman 1951; Ikacana 1971; my fieldnotes); kasheba with the Kaonde (my fieldnotes); muba with the Totale (Gluckman 1951; Ikacana 1971, who also mentions the neighbouring Toka); Lenje (my fieldnotes), or even groups further to the east, like the Lamba (Doke 1931) and the Ambo (Stefaniszyn 1964). 
The spread and contemporary distribution of non-ancestral non-regional cults of affliction show that Central African ethnic groups ("tribes") are not rigidly bounded, either geographically or culturally (cf. Van Binsbergen) 1975). The cults spread easily from one ethnic group to another, despite such great language differences as between Luvale and Lenje, Tonga and Lozi. Moreover, immigrant adepts from a distant ethnic group often proved acceptable as local cult leaders (a point emphasized by Symon 1959). Cult songs have sometimes been translated into a local language, but have often been retained in the original language of the ethnic group from which this cult was borrowed locally. Sometimes the original ethnic group even gave its name to the cult (songo, chimbandu). All this bears out the fact that, among other aspects, the non-ancestral cults of affliction represent an attempt to come to terms (both conceptually and interactionally) with the reality of extensive, inter-ethnic, interlocal contacts.

\subsection{Ritual}

Usually the differences between the non-regional, non-ancestral cults of affliction which occur in one area, are slight. There is somewhat of a tendency-it is not invariable-to associate certain paraphernalia (a peculiar type of headdress or scapular, miniature axes and hoes, fly-switches etc.) and certain bodily movements with particular cults. The main way, however, to tell one cult from another is from the contents of the songs that are chanted during the sessions. Below are some typical song texts: 1

Bakeshabe iyale yomana yowelile mama bamikupe iyale yomama

iyale yomama

Iyiyo mama yowelile

From kasheba, really, mother, I am ill, mother

from bamikupe, really mother,

I am ill, mother

o mother, I am ill

(text used alternatively for kasheba, bamıkupe and mushelu)

2

Tu ba kombele

biyaya bi neza

tu ba kombele

biyaya man

(text for biyaya)

3

Ba ka lenda mawulu mu pange

mu ni yoyise

lelo moyo

mu pange $m u$ n yoyise

bi nakunisisayela lelo moyo

ba nganga na ba nganga

kumpanga bafako

(text for kalenda-mawulu)
We pray

for biyaya has come

we pray

for biyaya, mother

For this foot disease, treat me to make me alive

today the life

treat me to make me alive

they don't restore my life today

these cult leaders or those cult leaders they don't treat me
These songs are sung by a small chorus of adepts, instructed and led by a cult's local leader, usually a woman. The adepts (usually women) stand in a semi-circle which is closed by a row of (male) musicians. Within this enclosure the cult leader and one or more novices dance, and enter into a trance. Before the session starts the leader has undertaken to treat the novices. She exhorts the latter, the chorus and the musicians so that the novices' movements may catch up and gradually harmonize with the music. Thus the novices may reach ecstasy. In the course of most sessions vegetal medicine is prepared from a selection of plant species which varies with each cult. Although each session tends to be dominated by the songs and ritual for one particular cult (the one in which the leader excels), often elements of other cults are used in abundance. This is particularly the case when a patient cannot be brought to respond properly to a session's main cult. Then one cult after another has to be tried in order to arrive at the correct diagnosis and treatment. Sessions last through the night and end at dawn with the final distribution of medicine to novices and adepts and occasionally to non-participant onlookers. For in contrast with the situation in the extreme north-west of Zambia, as described by Turner, in this area a small audience of non-adepts is present at every session, to share in the beer, to help out with the music, and to witness the patients' struggle for healing.

\subsection{Morality}

Part of the night's proceedings is, however, private: the therapeutic conversations which the leader and some senior adepts have with each novice. Their aim is to ascertain the specific personal conditions under which the affliction, dormant until then, has become manifest. Such conditions include a recent death, ill-will and suspected sorcery in the patient's environment, or the occurrence of a major healer, diviner or hunter among the patient's deceased kin.

The information obtained in the "anamnesis", however, is not fed into the patient's social environment. The information only serves to identify, to the officiants' satisfaction, the occasion at which the affliction agent chose to manifest itself. Even if this occasion highlights interpersonal conflict and illicit aggression (in the way of sorcery), moral redress, rehabilitation or prosecution never become the cult's concern. Once the diagnosis in terms of the cult's etiology has been pronounced, the cult tries to curb the invisible agent's harmful effects, but does not try to take away any group-dynamical causes of the misfortune. The non-ancestral, non-regional cults of affliction aim at individual readjustment. They fight symptoms of maladjustment but do not try to expose or resolve any underlying social tension. Nor are they meant to do so. These cults are concerned with suffering, and not with morality. Their frame of reference features patients afflicted by essentially unpredictable, non-human agents-and not

4 "Anamnesis" is used here in the technical, medical sense of a patıent's own account of the history of his complaint. 
victims injured by human evil-doers or by the effects (through ancestral revenge) of their own sins.

The non-ancestral non-regional cults, however, exist side by side with rival and alternative approaches to misfortune, which do emphasize morality and guilt, reparation and retaliation. Among the contemporary Nkoya, these rival approaches are frequently applied. They include: divinatory and redressive ritual in the idiom of ancestral intervention; similar ritual in the idiom of sorcery and counter-sorcery; litigation in more or less formal courts of law (Van Binsbergen 1976c); and finally regional cults of affliction, whose relation to non-regional cults with regard to morality I shall discuss below in section 3. A number of venues for redress are thus open to an individual facing misfortune. The choice is largely his own. He may apply to a diviner/healer known for diagnosis in terms of a cult of affliction, rather than to one who habitually propounds interpretations in terms of ancestors or sorcery; or he may apply to a court. The actor's underlying decision model is complex and can only be analysed on the basis of detailed description of the various institutions involved, and of specific extended cases. However, if one pursues the option of cults of affliction, this can be safely said to indicate one's reluctance to publicly present one's misfortune as caused by human conflict (sorcery, court) or guilty neglect in one's dealings with kin (ancestors). Such reluctance usually reflects lack of power, material resources and social support; the victim can neither answer a challenge through counter-sorcery and litigation, nor face such public disapproval as offences punished by ancestors inspire. Non-ancestral cults of affliction, however, interpret misfortune as an entirely individual condition which (in contrast with sorcery, ancestral intervention, or litigation) is not primarily determined by the victim's interaction with other people-although such interaction may form the occasion for the hidden affliction to manifest itself for the first time. Amongst the institutions dealing with misfortune, these cults have, therefore, a marked competitive advantage among certain people: those who are dependent, relatively powerless, and short of social credit. Little wonder, then, that most of the patients in the non-ancestral cults of affliction are women and youths. Mature and elderly men, as a rule, pursue other venues for redress. And if they involve themselves at all in such cults of affliction, it is not as patients, but (occasionally) as cult leaders, as musicians, and particularly as sponsors for their womenfolk.

This implies that at least for women, as patients, the cults of affliction do not provide an idiom of internalized powerlessness, but rather an alternative way to demand, and receive, male support - albeit outside the arenas where mature men compete with each other. This, of course, does not preclude such competition between leaders and sponsors (see Werbner, 1971; 1972: 235).

\subsection{Roles, Personnel and Organization}

For a successful session all the following conditions have to be met. The cult leader must be generally recognized and accomplished. The chorus (of a minimal size of four or five adepts) must know the basic song texts and must be prepared to assist in the proceedings. Musicians are needed who know or can quickly pick up the music peculiar to the various cults, and who are prepared to follow the directions of the leader. Musical instruments, beer and firewood are required. And finally, somebody has to organize and meet its expenses.

In a rural society where firewood is becoming less abundant, where beer has become a marketable commodity, and where drums and other instruments are scarce and privately owned, the logistics of the sessions often turn out to be quite complicated and problematic. Each session necessarily involves the sponsor, and the other participants in the session, in a network of transactions and obligations that both reflect, and bear upon, the extrareligious social process in the community. Good musicians cannot always be recruited from amongst a sponsor's close kin, and even if they can, they often demand a payment roughly equivalent to a day's wages. The adepts who constitute the chorus, do not receive any remuneration beyond a share in the beer that the sponsor furnishes for the cult leader. Besides this beer and occasional gifts of white cloth, bottled fizzy drinks, bottled beer and other luxuries, the leader receives a small sum of money for the diagnosis and treatment during the session. This sum is again equivalent to a day's wages. Even more important, the leader establishes a firm claim (actionable in court) against a much larger sum, easily a month's wages. This large fee is payable any time after the patient has made significant improvement-no matter what additional treatments are pursued elsewhere.

From the sponsor's side, therefore, the session involves immediate costs that are considerable, both in social and financial terms and, if the treatment is successful, heavy debts in the future. For the leader, the session means a significant gain immediately, and very likely a large financial claim in the future. At the same time, it also means a public test both of ritual skill and of such management power as is required for the mobilization of the chorus in the first place (it is the sponsor's responsibility to recruit the musicians), and for the leader's control over adepts and musicians during the many hours of the session. The adepts in the chorus clearly hold a key position. They are indispensible to the leader's success but hardly share in the latter's benefits.

The basic organizational form of non-regional cults of affliction is a small faction of loyal adepts around a leader, all living within walking or cycling distance from each other: within a radius not exceeding 10 kilometres, and usually much less. The leader can control the chorus' adepts in two cases, which often coincide: when the adepts are themselves still under a course of treatment with the same leader (and treatment may, partly for this reason, be extended over a period of years); and when the adepts are very close kin of the leader. Kinship ties among the Nkoya are, however, not automatically 
effective in bringing about and maintaining solidary social relationships. In order to be effective they need to be backed up by frequent interaction, e.g. through co-residence. Attachments between kin are readily disrupted as people change their residence in order to seek their economic and localpolitical fortune elsewhere, among a different set of real or putative kin. Such individual intra-rural geographical mobility is extremely frequent and, in fact, constitutes a major structural theme in Nkoya society. Likewise, the curative link between leader and adept is often threatened, both by rival leaders who compete for adepts (as well as for new patients), and by the senior adept's own aspiration to set up as a leader herself. Therefore, within (and between) the cultic factions tensions and conflicts are rife; and these tend to come to the fore during sessions, when the leader is most dependent upon the adepts. I have never attended a session that was not repeatedly interrupted by heated argument between the officiants. After a session there tend to be shifts in the faction's internal structure of relationships, and even in its membership.

The leader's status is rather insecure. Non-regional cults of affliction define the roles of leader, adept and novice, but they do not stipulate in detail the requirements by which one gets access to these statuses. These cults do not have a formal organization with fixed rules of eligibiity to office. Instead, recognized ritual leadership is a matter of public opinion. Whoever can persuade others to let themselves be treated by her, and can mobilize the necessary assistance, is a cult leader. On the other hand, a leader whose curative effectiveness begins to be doubted by many (partly as a result of her being forced out of competition by rivals) loses her patients and adepts.

How does one get launched as a leader? Long-term apprenticeship as an adept of an established leader is one way. In the take-off period as a leader, other standard methods to woo public opinion include self-appointed curative capabilities which are claimed to derive from dreams, from accession to the name of a deceased relative who was a well-known healer, or from a serious psycho-physical disturbance now overcome by a recoveryso that one is now acquainted, better than most people, with the experience of illness and death. Gradually, new songs (often featuring the name of the leader herself), an original choice of paraphernaliă, a notebook in which the names of treated patients may be recorded, fake or real licenses issued by local authorities, can all help to lend credibility and identity to the new leader. In this search for a personal "trade-mark", considerable expense and creativity is invested; even though the result is usually a permutation of the same limited set of elements used by all leaders and all non-regional cults of affliction.

The main condition, however, to make the grade as a cult leader is the construction of a local network of loyal adepts who can assist in the treatment of new patients.
My use of the term "faction" for the basic local unit of officiants, has suggested the problematic internal dynamics, the shifting membership of these units, and (as a major cause of this) the intense competition between units. In the immediate social environment of each afflicted individual, a number of leaders with their temporarily loyal adepts are active. Leaders are in competition with each other both for the senior adepts on whom their practice is dependent, and for new novices who will boost the leader's public status and bring in large fees.

The fees enhance a leader's power in two ways. Once received, this wealth is largely redistributed in non-ritual transactions with kin and neighbours. But since most fees cannot be paid immediately, they also tie the patients to the leader with heavy debts. Both ways, the leader's power must have considerable effect on the extra-religious social process. Moreover, the fees are so high and cash is so scarce in the villages, that the modern cults can be properly said to constitute a major redistributive economic institution. This holds true not only between villages, but also between village and town. Rural-based leaders treat afflicted urban migrants either by receiving them on short visits in the rural area, or by travelling to town at irregular intervals.

Both within and outside the religious domain, leaders hold enviable positions which they are constantly defending against the encroachment of others. As adepts and leaders have usually been initiated into more than one nonregional cult of affliction, and as the basic idiom of these cults is constant and well-known, an adept's shift from one leader to another (which often means: from one cult to another) presents no great difficulties in terms of knowledge and skills. Leaders greatly resent it when such a shift diminishes their effective following. For this reason, leaders tend to avoid each other and, when they operate within the same social field, are often at daggers drawn because of having snatched each other's followers in the past. Sometimes, however, leaders combine locally, stage sessions together and visit each other's sessions as guests of honour. On such occasions, emphasis is on manifestations of mutual professional respect, symbolized by the ostentatious furnishing of a chair for each leader ${ }^{5}$. But even then each leader is on her guard lest her colleagues make too favourable an impression on the audience, or attempt to lure adepts and patients away. Only when such professional contacts are backed up by residence in each other's proximity along with close kinship ties and good extra-religious relations in general, can they be seen to develop into stable, prolonged co-operation. In such a case leaders are no longer afraid of mutual poaching; they share patients and adepts.

These local ritual factions with their occasional co-operation between leaders, constitute all the rudimentary organizational structure that the

5 In this context one should bear in mind that most cult leaders are women, who in extra-religious public settings are not supposed to sit on chairs. 
non-regional cults of affliction possess. Leaders are predominantly ritual entrepreneurs, who exploit a local market on the basis of the population's general adherence to the cult of affliction model. Even between leaders in different localities who profess that they specialise in the same named cult (e.g. Viyaya), there is normally no contact-and often downright avoidance. Each may have learned this cult's ritual in a different place, may have added her own innovations, and would have her own local clientele to consider. The differences between the ritual performances of two such leaders of the same cult may be greater than those between leaders who avowedly specialize in different cults. Each elaborates on the general idiom of the cults of affliction in her own personal way, without any interlocal formal organization binding local leaders or dictating any orthodoxy. Public opinion is prepared to accept a leader's reputation and following as proofs of expertise, and it favours any innovation that does not greatly run counter to local canons of decency. But such public opinion concerning the cults is in itself mainly a response to the actions and pronouncements of the cult leaders. Thus it is by virtue of a widespread cultural model that each non-regional cult of affliction exists: each cult has its unstructured series of small factions which are disconnected, local and rather ephemeral. The widespread cultural model is continuously reinforced, at the grass-roots level, by the uncoordinated activities of hundreds of leaders in search of wealth, power, ritual prestige, and self-expression.

\subsection{Ritual Leadership as a Calling}

While exploring the political and economic dimensions of the non-regional cults of affliction, we should avoid reducing them to these and nothing more. Leaders, adepts, patients and outsiders are keenly aware of the economic and local-political aspects of the cults. Yet all of them consider the cults' healing efficacy their overriding justification.

The leaders, mainly elderly women, are not cynical operators and no more. They are gifted and passionate manipulators of symbols: song texts, paraphernalia, dramatic effects-and cash. Through an existential crisis earlier in life they have often paid the price (not just financially) towards becoming specialists in human suffering and some of its remedies. Their life-histories tell of prolonged illness, periods of insanity, ridicule by fellowvillagers confronted with the aspiring leader's first, clumsy attempts at being a healer, and more recently the treachery of once loyal patients who have at last set up as leaders themselves and no longer pay respects to one who, in her own view, fought for their very lives. A leader's strikingly intense and agile performance during the long nocturnal sessions may be partly motivated by a drive for money and power. But it has as much to do with art, while the prime concern is to heal a fellowman. If the ritual does not appear to succeed, it is not only a threat to professional prestige, but also compassion that forces the leader to exert herself for hours at a stretch, finally to bring the patient to join in the rhythm - thus making recovery possible.
Better than anyone else, the leader understands and believes in the idiom of the cults of affliction. She is the mediator of a conceptual system which is commensurate with the changing social order in which she and her patients find themselves. Offering deliverance from suffering is a professional calling for which the easy life, food, marriage, all have to be sacrificed. The leader Kashikashika vividly describes how her calling affects her life:

"At home I have no time to eat. I eat with one hand, keeping one hand on the head of a patient. (Laying-on of hands is a minor form of treatment in the cults in which she specialises.) I have no time to dress, but instead walk about in my short petticoats. I have no time to sleep. In the middle of the night people come and knock at my door for treatment.

"Years ago, a man fell in love with me and wanted marriage. I told him: 'Before I go and live with you, realize how my calling affects my life. I shall often have to go out in the night. Sometime I shall have to stay away from you for three months at a stretch, to attend to my patients! But he did not want to listen and went ahead with the marriage. After a month he started complaining, and we soon divorced. Now I am married again, with one of my patients. He says: 'Look, she has cured me. Should I complain when she goes out and stays away to cure others like me?...',

The husband is present and amply confirms that this is indeed his view of the matter.

Underneath this testimony of professional sacrifice there is, unmistakably, a note of pride and female power quite characteristic of elderly Nkoya women, and of cult leaders a fortiori. But at any rate, calling obliges; and many leaders have strict personal standards as to the size of fees, the requirements for proper diagnosis, and the ethics of dealing with un cooperative debtors amongst their patients. ${ }^{6}$ Without exception, leaders have themselves suffered, in the past, from the afflictions they treat, and usually they are still in frequent silent communication with their own affliction agent, inside. Allegedly, the agent advises on the leader's well being, but he does not take mockery and is sure to punish a cheating leader of his cult. Adepts and patients are aware of this security device, too, and as a rule expect fair play from the cult leaders they deal with.

The high revenues and other benefits in terms of power and prestige associated with cult leadership, can hardly fail to appeal to the ambitious and calculating sides of the incumbents' character. Yet I would maintain that the requirements in terms of artistic and emotional dedication, and in terms of self-confidence vis-a-vis the symbols manipulated in the cults, are

6 This might be read to constitute a moral aspect, in contrast with what I have said above about the amoral nature of these cults. However, this concern with fair play points in a different direction - just as the ethics of fair play do not turn soccer or the retail trade into a predominantly moral institution. 
such as to make the sham leader, who stages for money's sake a ritual whose efficacy she secretly denies, a rare occurrence.

\section{Regional Cults of Affliction in Western Zambia: General Characteristics}

Due to a succession of non-regional cults of affliction that had been spreading over Western Zambia for several decades, the general idiom of such cults had become established by the 1930's. By this time the new type of regional cult of affliction emerged. So far, three cults of this type have been studied: Nzila (also known as the Twelve Society), Bituma, and Moya. It is likely, however, that Western Zambia has witnessed the rise of several more, which subsequent research may throw light upon. The first description of Nzila is by Reynolds (1963: 133f), on the basis of an administrative report by 1.H. Whethey in 1957.? In 1972, Miss M. Muntemba carried out research into this cult, mainly in the Livingstone area (Muntemba 1972); I am greatly indebted to her for the lengthy conversations we have had on the subject. The Bituma cult played a major role in my Nkoya fieldwork (cf. Van Binsbergen 1972a for a preliminary account of the cult). Ranger (1972) gives lengthy excerpts from both Muntemba's and my own descriptions. The Moya cult is briefly discussed by Ikacana (1971: 33); although this author mentions the healer Liminanganga as this cult's main leader in Kaoma (then Mankoya) district, thus suggesting a certain centralization that is characteristic of a regional cult, his further discussion gives the impression that by the 1940's Moya was a non-regional cult. During my fieldwork in the early 1970's, however, a regional cult of the same name was active in the eastern part of the district, where, headed by a prophet called Moya after his cult, it had penetrated only a few years previously - but perhaps not for the first time. My limited data on this cult do not enable me to decide whether it became a regional cult only recently, or was already one in Ikacana's time.

Like the factional, non-regional cults described above, these three regional cults are cults of affliction. They interpret disease and misfortune by reference to a non-human agent, and attempt to redress the disorder through divination and subsequent initiation into the cult. As cults of affliction deriving from the same cultural area, the regional and non-regional cults have on the surface much in common. However, there are very significant differences between the two types.

The most strikıng aspect of Nzila, Bituma and Moya is their regional organization. These cults each have a central place, which is the seat of the cult's supreme leader. Cult officers appointed by the leader are responsible for sections of the total area over which the cult has spread. They communicate regularly between local cult congregations and headquarters. In close

7 Mongu district files; the report could not be consulted. cooperation with the supreme leader, they recruit new local adepts and leaders, enforce observance of the cult's regulations (e.g. concerning the size of fees for treatment, and the forwarding of a portion of the fees to headquarters), supervise the ritual locally, and guard against undue autonomy and ritual deviation of local leaders. In contrast with the non-regional cults, effective leadership of a local congregation depends not so much on the manipulation of public opinion and the control of a loyal local ritua following, but primarily on admission and promotion within the cult's hierarchy, subject to approval from headquarters. Literacy, in its simplest forms, plays a role; one may keep a record of the number of patients healed, of their names, and of the fixed fees for each type of treatment. The regional cults are more or less formal organizations that enforce, among local cult leaders, ritual conformity, compliance with the cult's authority structure, and the forwarding of funds, over areas of many thousand square kilometres.

We have seen how leaders in non-regional cults of affliction tend to make considerable innovations upon the cultic material they use. Also, these leaders have usually gone through deep personal crises before establishing themselves as cult leaders. In these respects they have much in common with the founders of Nzila, Bituma and Moya. However, in the case of the nonregional cults a leader's specific innovations and personal history are played down as irrelevant. The leader is viewed not as the inventor but as the mere transmitter of cultic forms which, allegedly, have already existed elsewhere and which could have been made available locally by any other leader. The regional cults, by contrast, are quite sharply considered to be founded by a particular prophet, whose name, visions, life history, the process in the course of which he shaped his cult, are all held to be very important and are often known even among non-adepts. In contrast with the leaders of nonregional cults of affliction, Chana (founder of Nzila), Simbinga (founder of Bituma), and Moya (founder of the Moya cult) all started out as charismatic leaders in the Weberian sense (Weber 1969: 358f). Each displayed what I have elsewhere (Van Binsbergen 1976d: 71) called the "standard biographical pattern for Central-African religious innovators'. Each reached prophethood through the same stages. Falling victim to a chronic disease or defect is a first stage. Chana was a leper and suffered from the bindele affliction which, however, the non-regional bindele cult proved unable to cure. (Later the difference between Chana's affliction and bindele was acknowledged by renaming the former nzila: "path".) Simbinga and Moya likewise suffered from afflictions of a nature until then unknown. In the next stage the affliction would develop to a crisis (which in the cases of Simbinga and Moya allegedly involved temporary death, in Simbinga's case even burial). In this crisis the prophet allegedly received very specific messages and directions from the supernatural agent claiming responsibility for the affliction. Following the indications received in the messages, the prophet would be able to recover. He would then have the power and the calling to apply his new insights to those in his social environment who were 
similarly afflicted. These first patients (twelve in Chana's case, seven in Simbinga's) would form the original core of the cult, soon to be augmented through the combined efforts of prophet and initial followers.

The regional cults do not merely share the affliction-cult idiom with the nonregional cults. The former actually emerged upon the substratum of these earlier, non-regional cults. All three started as an individual's response to an affliction that could have been cured within the established non-regional cults of affliction. Instead, the three patients devised their own cults.

Now why did these three prospective prophets fail to get healed within the existing non-regional cults of affliction? For all three, contemporary informants claim that they had tried such treatment; in Chana's and Moya's case, modern medical services were consulted as well. The standard course of their crises suggests that, in addition to any bodily disorders, a profound mental struggle was involved, bearing on existential problems such as the meaning of suffering and the interpretation of the universe. The then current, non-regional cults revolved around affliction-causing agents of an abstract and hardly personalized nature, mainly conveying associations with alienness and neighbouring ethnic groups. The solutions the three prospective prophets were seeking were to be-to judge from what they came up with-of a less particularistic and human scope. In the accounts of the founders' original visions and in their current interpretations of affliction cases and their treatment, the three regional cults propound strikingly similar, new conceptions concerning the nature of the supernatural agents involved in affliction. Chana, Simbinga and Moya attributed their visions, their miraculous recovery and their subsequent healing power to entities closely associated with or, identical to, the High God. In Chana's case this was a spirit who in dreams and visions manifested itself as a white being, exhorting him to acknowledge God, invoke God's help, and preach about God to his patients. Simbinga had similar visions, which he interpreted in terms of an Angel (Angero) from God. Moya's interpretations concentrate on the Life-Spirit (Moya), source of life and capable of dispensing health and illness at will. These are concepts of a much greater universality and with much more specifically theistic connotations than the affliction-causing principles of the non-regional cults.

But while this conceptual shift may have primarily sprung from the specific existential problems of the three prophets, the latter were at the same time yielding to a general tendency which since the beginning of this century has been encountered in quite a number of religious innovations in Western Zambian. Most of these movements had no specific concern with healing. They include a number of Ila prophets, amongst whom is the great prophet Mupumani (1913) whose movement had an impact throughout Western Zambia and the surrounding countries; minor eschatological prophets in Mamwala, Kalabo and Mwinilunga; the numerous Watchtower preachers and dippers moving through the area in the late 1920's and the 1930's; and even the Christian missionaries. All these religious innovators displayed the same conceptual shift towards ever greater prominence of the High God (Van Binsbergen 1976d).

A final major difference between the regional and the non-regional cults of affliction is that the former do display a moral element which, as we have seen, is lacking in the latter. Chana was instructed by the Spirit:

"to teach the people what to do and what not" (Muntemba 1972; 2).

\section{He was given}

rules and instructions he was to teach his people at the Sunday afternoon gatherings.(...) the rules centre around purity of mind and spirit as the key to a healthy body. At the Livingstone branch service about one hour and thirty minutes are given to instructing the people, in the form of question and answer, in how to attain purity. (...) Members are exhorted to keep clean thoughts and clean minds by not bearing malice against their husband or wife, their brothers, sisters, in-laws and neighbours but instead to love. They are warned against bearing false witness, to avoid quarrelling and drink, drink which often leads to quarrels and other irresponsible acts. They are admonished against eating certain foods (...) which are considered unclean and which would therefore foul the body and soul of man" (Muntemba 1972: 5f).

Reynolds gives a similar picture and emphasizes the patients' surrender of sorcery apparatus in this context $(1963: 135,138)$.

In the teachings of Simbinga and Moya the same emphasis on purity versus pollution is encountered. For them, the whole range of local medicine represents evil and pollution in its fundamental form. When Simbinga was called to prophethood in the early 1930's, he immediately launched a fierce attack on local herbalists, diviners, and leaders of non-regional cults of affliction. He wanted them to give up their manipulations of material apparatuses, paraphernalia and medicine, and instead accept his own interpretation of misfortune (which by this time, however, was still blurred and inconsistent), and his treatment by means of laying-on of hands, prayer and dancing.

This is a moral issue for various reasons. First, much local medicine was (and is) locally applied for purposes which, however common in the loca society, were considered immoral acts of sorcery: to attain excessive power and success; to harm or kill rivals and enemies. Moreover, especially the most powerful medicine derived from sinful manipulations of human bodies that were killed or desecrated for the purpose. And finally, on the basis of his visions Simbinga, like the two other prophets, presented an alternative theory of causation of affliction, whose universalist and theistic overtones implied a moral rejection of previous, medicine-centred interpretations. 
Simbinga was at first unsuccessful in his attack. The local practitioners proved disinclined to accept his views. They mobilized public opinion proved disinclined to leave his against Simbinga and after a relapse of his alfiction he hambezi-area) area. He travelled to the north-west (to the Balovale-now Zambezi-area). After a few years he returned with a revised version of his cult. This time material paraphernalia, divining apparatus, and vegetal medicine had been material paraphernalia, in the Bituma idiom. However, the cult has retained given a prominent place in the Bituma idicine and material apparatus, and its abhorrence of all other forms of medicine and material apparatus, and still considers envy, rivalry and sorcery the main occasions upsetting the harmony between a man and his Angel-interpreting the Bituma affliction as the manifestation of such disruption.

The Moya cult has adopted a rather similar position. But whereas Bituma, though conscious of the dangers involved, does not absolutely forbid its adepts the possession and manipulation of medicine, Moya does-including ades then modern dispensaries. In both hunting or fishing medicine, or products from minully aware of the dangers cults, adepts and particularly leaders are continually aware of the danger of pollution that threaten them everywhere. For this reason they may avoid certain persons and activities. However, beyond the reluctance to apply certain peron the purity-orientated sorcery medicine to further their own interests, the purity-orits appears to have little impact on everyday life.

For even if the regional cults differ from the non-regional ones with regard For even if the regional cults differ from the no more fundamental respect. to moral connotations, they are quite similar in a more fundamental respect. Both types of cults are based solely a matter of the relationship misfortune: These cults do not between victim and an unpredictable supernats in which the victims are link misfortune to the small-scale social proceses in which the victims involved, and therefore cannot have a direct impact on such processes.

There is an intimate relation between these three outstanding features of the There is an intimate relation between these the appeal to more universal, regional cults: their founders' charisma, the appeal to more universal, theistic supernatural agents, and the introduction of a moral element. In the idiom of spirit possession, association with alien or neighbouring ethnic groups might well provide a basis for personal charisma seems less effective in a society where through interlocal contacts across ethnic boundaries, such association has become commonplace over the past century, and where a considerable variety of religious innovatory movements have already ffected an overall tendency towards greater prominence of have already effected an overall tendency towards greater prominence involving the High God. Under these conditions, visionary experiences involving supernatural entities of a much wider scope are more likely to endow exceptional individuals with the charismatic qualities that could lead to exceptional individuals with the charea. In other words, I suggest that the founders' charisma, and their propounding of universalist, theistic supernatural agents, imply each other.
Although universalist, theistic concepts were circulating in the area well outside the sphere of missionary Christianity, the three prophets started out under the latter's direct influence. Prior to their appearance as prophets, both Chana and Simbinga had been thoroughly exposed to missionary Christianity. Chana's parents had been converts of the Seventh Day Adventist Church, and Chana belonged to this church before his prophetic calling. He even continued to adhere to this church while heading the Nzila cult (Muntemba 1972: 7f. Reynolds 1963: 133f suggests the contrary). Simbinga was among the first evangelists of the fundamentalist South Africa General Mission at Luampa, and appears to have received further Christian teaching as a labour migrant in South Africa. Although very little is known yet of Moya's biography, the preponderance of Christian elements in the ritual of his cult (bible copies, church bells, and a supernatural entity whose name is the current local translation of the Christian concept of the "Holy Ghost") reveals a similar background.

If the universalist, theistic elements endowed the prophets with just the amount of charisma they required to set up regional cults, their propounding of moral elements fits well into the same picture. As Weber (1969: 361) wrote, "From a substantive point of view, every charismatic authority would have to subscribe to the proposition, 'It is written..., but I say unto you...' The genuine prophet, like the genuine military leader and every true leader in this sense, preaches, creates, or demands new obligations".

However, the development of a regional cult organization is an aspect not of charismatic leadership itself, but of its subsequent routinization (Weber 1969: 363f). Given the charisma, universalist and theistic agents, and moral emphasis by which the regional cults differ from the substratum of nonregional cults of affliction from which they sprang, the development of more or less formal interlocal organization does by no means follow automatically. Instead, such development represents a major analytical problem. Apart from the ill-documented Moya cult, we are fortunate in having, in the Nzila and Bituma cults, two reasonably well-known cases whose development into regional cults displays such divergence, that a detailed comparison is likely to yield some insights into the general dynamics of regional cults.

\section{The Development of Nzila and Bituma as Regional cults}

4.1 Nzila

After a spell of labour migration in Zimbabwe, Chana returned to his village in Kalabo district. He developed his affliction, cured himself through the methods shown to him in his visions, and appeared as a prophet in the early 1940 's. ${ }^{8}$ His methods involved the erection of a shrine, daily ablutions in

8 Reynolds (1963: 133) mentions the date of 1944, Muntemba (1972: 1) 1940. 
this shrine with water medicated by selected herbs, and nocturnal ritual dances. Having recovered, Chana successfully applied this method to his first twelve patients, thus obtaining his first followers: the twelve first Nzila "doctors". Subsequent visions instructed him to put faith in God, to organize weekly services for Him on Saturday afternoons and to extend his activities to moral teachings. Thus a formal ritual routine was worked hut quite reminiscent of a Christian church service; the influence, in particular, of the Seventh Day Adventist Church is unmistakable (Muntemba particular, of the Seventh Day Adventist Church is unmistakable (Munt Reynolds 1963: 137). Assisted by his doctors, Chana treated a rapidly increasing number of patients in the Kalabo, Mongu, Senanga and Kaoma districts. A cult centre was erected near Mongu, the capital of the then Barotse Province (now Western Province). The growth of the cult was such that already in 1952 a larger building had to be constructed. At the cult centre, Chana would personally diagnose the patients' affliction as his own. After the diagnosis, the patient would return to his place of residence, where under the guidance of one of the doctors he would construct a windbreak in which he was to wash every morning, using medicated water. This would be continued until the patient appeared to be cured-which could take up to five months. Patient and attending doctor would then apply again to the cult centre, where Chana would subject the former to a series of tests in order to ascertain if he was truly cured. Some of these tests would be public and within sight of the weekly gatherings at the centre, whereas the final test would take place in Chana's sacred enclosure (Reynolds 1963: 136f). This finished, the patient would be told what he had to pay:

'Payment is normally in the form of livestock; a cow, a few pigs or goats, but frequently, a fairly substantial sum of money has to be paid. He must also bring a beast to slaughter for the feast that night' (Reynolds 1963:137).

During this feast the cured patient would be installed as a new doctor of the Nzila cult. This gave him the right to build his own sacred enclosure at his own residence. He would have authority to attend on new patients during their months of ritual washing, but could not use his own sacred enclosure to diagnose or pronounce final recovery: this would have to be carried out at the cult centre, by Chana personally.

In the mid-1950's the Mongu centre under Chana's direct leadership catered for the Mongu, Kalabo, and Kaoma district; a subsidiary branch, led by one of the twelve doctors, was then already in operation in the Senanga district. Branches soon began to proliferate. Muntemba (1972: 3) reports that

"By the late 1950's it (the cult) had spread to most areas in Zambia that had strong Western Province influences and also to Bulawayo and parts of Botswana. In the 1960's branches were started in most towns along the line of rail including the Copperbelt. (...) People not only from Western Province but from other societies became Nzila members as well. The movement was registered as the Zambia Nzila Sect in 1966. Its membership stood at 80,000 people then. On 30th March, 1972, the membership figure stood at $96,872 . "$

Thus in a quarter of a century the Nzila cult developed from a core of a handful of followers around a charismatic leader, into a fully-fledged interlocal formal organization with government recognition, branches and property (in the form of buildings for worship) in most major towns of Zambia. The supreme leader's personal control over the crucial stages in the healing of each patient became, of course, no longer practicable. Branches and their leaders now enjoy a certain autonomy, which is however effectively checked by an interlocal organizational structure ensuring overall conformity of both belief and ritual, central administration of membership figures, and centralised control over the recruitment and performance of officers. This control is effected by the Annual Convention at the cult's headquarters, by the distribution of essential paraphernalia, ${ }^{9}$ and by formal examinations concerning the cult's beliefs and regulations.

Here a creative process must be appreciated in order to see the general significance of this development of a regional organization in the Nzila cult. Imitation is not the crux of this development; Nzila is far more than a mere copy on the model of a Christian church. A failure to appreciate this leads Wilson (1975) to a radical misreading of the cult, and a wrong generalization about the primacy of imitation in the organizational development of sects. From Reynolds' account of Nzila, Wilson (1975: 92f) wrongly infers that Nzila developed no other congregations than the Mongu one over which Chana presided. Wilson goes on to speculate that

"the abilities and facilities necessary for a more elaborate structure, however, were probably not yet available in Barotseland. Only where an organizational model of another type of movement can be imitated should we expect thaumaturgical responses (such as witchcraft-eradication movements and cults of affliction-WVB) to take on these structural characteristics which we associate with sects in advanced society. Such imitation, combining central direction with branch churches over a wide area, first occurred in this region in the Lumpa church." (1975: 93f).

Applied to the Lumpa church of Alice Lenshina the explanation in terms of an imitation of the mission as organizational model (Wilson 1975: 94f) is gross and superficial-particularly in view of Roberts' authoritative statement that "there is very little information of any kind on the internal organization of the Lumpa church-a most important subject which perhaps will never properly be elucidated" (Roberts 1972: 3; see also Ranger 1973, for a critical review of Wilson's approach, and Van Binsbergen 1977b).

9 Initially a jar of chalk, and church bells (Reynolds 1963: 135, 137); later also a sacred cup for the administering of medicine (Muntemba 1972: 5,11 ). 
Wilson's errors are plain. Nzila did evolve branches over a very wide area, and even Reynolds mentions the early Senanga branch. Therefore, the structural requirements for a regional organization were obviously met in Barotseland in the 1940's. The Bituma and Moya cults, as I will discuss below, show that Nzila was not even the only cult to develop such regional organization. Admittedly, all three cults borrowed part of their idiom from Christian churches (this is clearly what Wilson means by "another type of movement"). Moreover, the fact that Nzila was embedded in a social environment dominated by formal, bureaucratic organizations (including Christian churches) appears to have favoured Nzila's expansion (see section 4.4 below). Nevertheless, it is a gross error to explain the development of regional organization as merely an imitation of the Christian church model. Such an explanation wholly ignores the creative process by which new organizational solutions have been gradually worked out in Nzila and similar cults. These solutions were primarily determined not by the desire to imitate an outside organizational model, but, as I demonstrate in the following discussion, by the founders' personalities, their relations with their early followers and the structural characteristics of the cults' regions.

\subsection{Bituma}

The development of Bituma is much less of a success story. Simbinga's first attempt to found a cult failed. Public opinion rejected his claims of prophethood. His first activities (which included the propagation of unusual healing methods and the free distribution of his herd of cattle) were considered the acts of a madman. His early attack on what he considered the impurity of established healers and diviners, including his cousin Kapata, contributed to his public rejection. He left the area. However, when he returned in the late 1930's, he was in possession of an elaborate collection of paraphernalia, ${ }^{10}$

10 The paraphernalia which Simbinga brought from his journey, and which to this day are in possession of his widow (one of my chief informants), were mainly the following. In three differently-coloured bottles (allegedly brought from following. In three differently-coloured bottles (allegedly brought from
Johannesburg by somebody else, and for secular purposes) Simbinga had collected water from three rivers: the Zambezi, the Kabompo and the Lungwebungu. Thes bottles he used as divining device: only a patient who managed to indicate which bottle contained water from which river could be considered to suffer from Bituma, and thus be eligible for treatment. In addition Simbinga brought a round, grey stone (about $10 \mathrm{~cm}$ diameter); a mpande shell partly covered with copper-wire; a flyswitch made of eland-tail; a number of cowrie shells; a genet skin (mbomba) circular orte of eland tail; a number of cowre shells; a genet skin (mbomba), a circular ornam a small copper bell of European manufacture; and finally a leather-bound copy of an Afrikaans hymnbook (Di Berijmde Psalms, 1936). For the healing ritual, Simbinga would dress in fully white clothes. Although I cannot elaborate on this point here, to one familiar with the material culture and symbolism of Western Zambian cultures it will be clear that Simbinga's choice of paraphernalia was largely based on widespread conventional symbolism in this area, and reflected

personal idiosyncrasies only to a limited degree-except in their combination. and much more developed views concerning the nature of the afflictioncausing Angel. The affliction henceforth became known as Bituma ("sent him") or Chituma ("message"), referring to Simbinga's prophetic commission or (according to other present-day informants) to the Angel, who sends affliction and is himself sent by the High God. Simbinga shifted the area of his activities towards the east: the central and eastern parts of Kaoma district. There he treated his first seven patients, including Kapata. Kapata, and several others among these first followers, only joined Bituma after a career of intense personal crises involving previous initiation into such nonregional cults of affliction as kayongo and mayimbwe. In this respect they were Simbinga's junior colleagues, rather than his disciples; they had access to experiences similar to those on which Simbinga's charisma was based.

Simbinga built for himself a small, hut-like shrine (called kreki, "church") and made his initial followers do the same at their own places of residence. At these shrines healing sessions would be held at irregular intervals, according to the demand from patients. The session would start and conclude with prayer, and be built around songs featuring Simbinga and crucial signs of his prophetic calling: his communication with heaven, and his rising from death:

1

Tukuyako, tukuyako

ku ngonda, ku ngonda

We are going, we are going

to the moon, to the moon

(allegedly the first song Simbinga composed when he rose from death, claiming that he had been at the moon).

2

Thangwe ngoma

ngwa Shimbinga here comes Simbinga

Start beating the drum

(a song Simbinga used during ritual dances in the first years).

3

Kombelela nganga

wayamukalunga Shimbanda-mwane you were in the grave, Great Healer, nganga yetu yele

kombelele nganga

wayamukalunga Shimbanda-mwane you were in the grave, Great Healer,

Shimbinga-mwane kombelelelanga we are continuously clapping hands

wayamukalunga mwane

Kapata yele kombelele nganga

for Simbinga the Great

Great one, who were in the grave

Kapata indeed we clap hands for the cult leader

wayamukalunga mwane Great Ohe, you were in the grave

(a major song of the later period).

However, despite such distinctive elements as the regional organization centring around a charismatic leader, the theistic interpretation of affliction, 
and the purity-centred morality, the Bituma sessions in themselves remained, in their outside appearance, very close to the general idiom of the nonregional cults of affliction described above.

The cult took on well in Kaoma district, where in the 1940's-1960's a few thousand people were initiated. A more precise number cannot be given since in contrast with the Nzila cult no central records of membership were kept. (Individual leaders did keep records of their own patients, along with a price-list of various treatments available.)

In addition to the seven initial followers, about a dozen more leaders were appointed during Simbinga's lifetime. These leaders would meet each New Year's Day at the cult's Annual Convention around Simbinga's shrine, where they would hand over part of their patients' fees and would enjoy a collective meal of white chickens.

In the 1950's several leaders settled in Lusaka and other line-of-rail towns, where they held sessions for urban migrants from Kaoma district.

Meanwhile old tensions between Simbinga and Kapata (going back to the time of Simbinga's first appearance as a prophet) became manifest again. They concentrated on the cult's leadership and on the use of the cult's funds. Simbinga had married a woman from the eastern part of Kaoma district and enjoyed the loyalty of the Bituma leaders there, several of whom were his close affines. Kapata had settled in the central part of the district, and other Bituma leaders there sided with him. Simbinga's sudden death during a hunting party (1960) was the occasion for the cult to fall apart. The leaders around Kapata (including those in town who hailed from the central part of the district) accepted his succession to the cult's leadership. They continued to visit the Annual Convention, now at Kapata's shrine, and to forward part of their fees to him. Those in the eastern part of the district (and urban leaders hailing from there) have severed their connection with the cult's organization and have since practised the Bituma ritual as independent, individual cult leaders, without any organization being maintained between them. For them and their patients, Bituma has lost its regional character and has become merely another non-regional cult of affliction among the many prevailing locally. These eastern leaders retain a reminiscence of Simbinga's original, theistic and universal visions. However, for those of their patients that have been initiated only recently, these associations are virtually lost. Surviving only in the central part of the district and among a few urban leaders, Bituma has elsewhere returned to the substratum of the factional, non-regional cults from which it sprang.

Thus the development of Nzila and Bituma has been very different indeed. We shall presently try to identıfy some of the factors responsible for this difference.

\subsection{Bituma and Nzila compared from within}

Let us first look at both cults from within: their internal structure and specific idiom.

As Reynolds rightly observed (1963: 137), during the first two decades of Nzila, Chana succeeded in maintaining control over crucial phases of the ritual. He kept most of his doctors in the position of mere assistants, without autonomous ritual powers. Only Chana's heir (nominated by Chana himself), and presumably his Senanga deputy, were allowed to exercise ritual powers on their own behalf. As the cults spread further, effective devices were worked out to safeguard the cult's unity and perpetuation even when it ramified into a number of geographically distant branches. A body of centralized administration, the Annual Convention, explicit regulations, indispensible paraphernalia whose distribution was strictly controlled, all in combination constituted an adequate. structure through which the founder's charisma could be routinized and channelled without becoming dissipated or usurped. These devices constitute clearly recognized principles of legitimation, controlled from headquarters, outside which no cult leader pursuing the Nzila idiom could claim ritual efficacy. The gradual adoption of these devices rendered an ever-increasing specific identity to the Nzila cult. It more and more diverted from the substratum of non-regional cults. Nzila's interpretational idiom and cultic procedures became so specific that a relapse into the non-regional substratum became increasingly unlikely.

This may have been due not only to the cult's internal authority structure. Through the very large number of adepts and the participation of nonadepts in the mass services (Reynolds 1963: 136), the Nzila cult must have become something of a generally recognized social institution in the society of Western Zambia. Nzila's definition and perpetuaton came to be based not just on concepts and actions of leaders and adepts within the cult, but also on public opinion. The latter's influence is suggested by the one case of a break-away from Nzila cited by Muntemba. There the protagonist had to adopt an idiom explicitly different from Nzila; and even so, Nzila turned out to be so well established that after a temporary decline the population again made a mass demand on its services:

"Two years ago Nzila was thought to be on the decline in the Mulobezi area when a former Nzila healer decided to leave the sect to concentrate on pure faith healing which he thought (and Christian leaders accepted) was more Christian. People went to him from all over Livingstone area and his activities met their needs. Yet now this man's authority is on the decline as more people turn back to Nzila." (Muntemba 1972:11f)

A very specific ideology and ritual, and a well-defined structure of organization and authority, externally supported by expectations among the general population, produced for Nzlla effective checks against the threat of fragmentation and kept the cult from returning to the non-regional phase. 
By contrast, Simbinga failed to assert himself as a continually indispensible source of charisma vis-a-vis the other Bituma leaders. Once initiated, the latter could all act independently. Moreover, at least some of them had had experiences similar to those from which Simbinga derived his charisma. Simbinga's personal status in Bituma was far less exalted than Chana's in Nzila. The great benefits in terms of prestige, power and income attached to independent leadership along the non-regional model, produced a strong tendency towards fragmentation. Little could counteract this tendency but the leaders' personal emotional attachment to Simbinga, which ceased to have organizational relevance when he died. Moreover, in order to possess ritual efficacy in the eyes of adepts and of the general population, Bituma leaders were by no means dependent on paraphernalia that could only be obtained from the cult's headquarters and that, once obtained, would only be regarded as legitimating leadership as long as their owner continued to belong to the cult's organization. Instead, Bituma leaders freely obtained and augmented their paraphernalia, which were similar not only to Simbinga's but also to those in use in the non-regional cults of affliction: white clothes, scapulars, fly-switches, bells, etc. And although the cult certainly became an established institution in Kaoma district, in its public manifestations it remained so close to the well-established nonregional cults of affliction, that any external check (n the way of expectations from the general population, concerning ritual and organization) against relapse in the direction of these non-regional cults, could not have been strong.

As a regional cult, Bituma was far less powerfully desıgned than Nzila. Not so much Bituma's decline, but its part survival around Kapata seems to pose a problem. Personal ties based on past treatment supported the relationship between Kapata and his loyal leaders after Simbinga's death. In addition, however, there appear to be more systematic reasons for the survival of Bituma in the central part of Kaoma district, which will become clear as we now turn to a discussion of the structural characteristics of the regions of Bituma and Nzila.

Let us sum up the position. Nzila and Bituma sprang from the same substratum of non-regional cults of affliction, and both were triggered by very similar personal experiences of their founders. What then explains their their very different development? Part of an answer lies in personality differences: Chana was clearly a more creative innovator and organizer than Simbinga. Another part lies in the nature of social relationships between the leaders and their initial followers: in contrast with Chana's selfconfident and unchallenged control, Simbinga was much more of a primus inter pares and had to compromise with the cultic backgrounds and ambitions of his initial followers. The differences between the cults' organizational structures and ritual idioms as they were gradually worked out, provide, as a third part of an answer, such explanations as I have just attempted to give in the present section. However, it would appear that these organizational differences in themselves largely derived from the differences in structural characteristics between the Bituma and Nzila regions.

4.4 Nzila's and Bituma's Regions Compared

Although the regions of both cults extend into towns outside Western Zambia, the processes that have shaped the cults in the first two decades after the founders' first appearance as prophets have taken place within Western Zambia. I feel therefore justified in concentrating on that area, and I refrain from discussing the cults' wider ramifications.

Map 2 outlines the geographical location of the regions of both cults in this area, and indicated the main direction of spread. By comparison with Map 1 and with the geographical material contained in Davies (1971), a number of striking differences between these two regions can be observed.

Demographically the differences are considerable (Davies 1971:42-47). The Nzila region has, by and large, a higher density of population. In addition to small administrative centres at Kalabo, Senanga and Sesheke (which are perfectly comparable to Kaoma in the centre of the Bituma region), the Nzila region includes the only two significant towns in this area: Mongu and Livingstone. ${ }^{11}$ Nzila's headquarters are near Mongu, whilst the Livingstone area (extending into the commercial timber concessions around Mulobezi) appears in Muntemba's description as a major growth area of Nzila. By contrast Bituma has been a rural affair, whose present headquarters are located at about 25 kilometres from Kaoma. Admittedly, Bituma does have a few hundred urban adepts: but these are almost exclusively lower-class migrants from Kaoma district who, unable to become stabilized urbanites, keep circulating between town and village, and in many cases go through the Bituma ritual not in town but in the village. The occurrence, in the Mongu and Livingstone-Mulobezi area, of male/female sex ratios of more than 100 (as compared to under 70 in the Bituma region) further bears out the demographic difference. ${ }^{12}$

The demographic situation has important implications for the regional cults. Where population density is low (in the eastern part of Kaoma district it drops under 7 inhabitants per $\mathrm{km}^{2}$ ), the creation of local congregations and the maintenance of interlocal ties between them poses serious problems in terms of the number of people available, transport, and

11 In the 1969 census Mongu had 10,700 inhabitants, Livingstone 43,000 inhabitants, and the other centres mentioned less than 4,000 inhabitants (Davies 1971: 126)

12 Despite increase in population, the relative demographic difference between the Bituma and Nzila regions was of essentially the same nature as in the 1930's, when Mongu and Livingstone had already been provincial and national capitals rongective for respectively for several decades, and (cf. Merle Davis 1933, appendix map) population density in Western Zambia showed variations similar to the present-day distribution. 


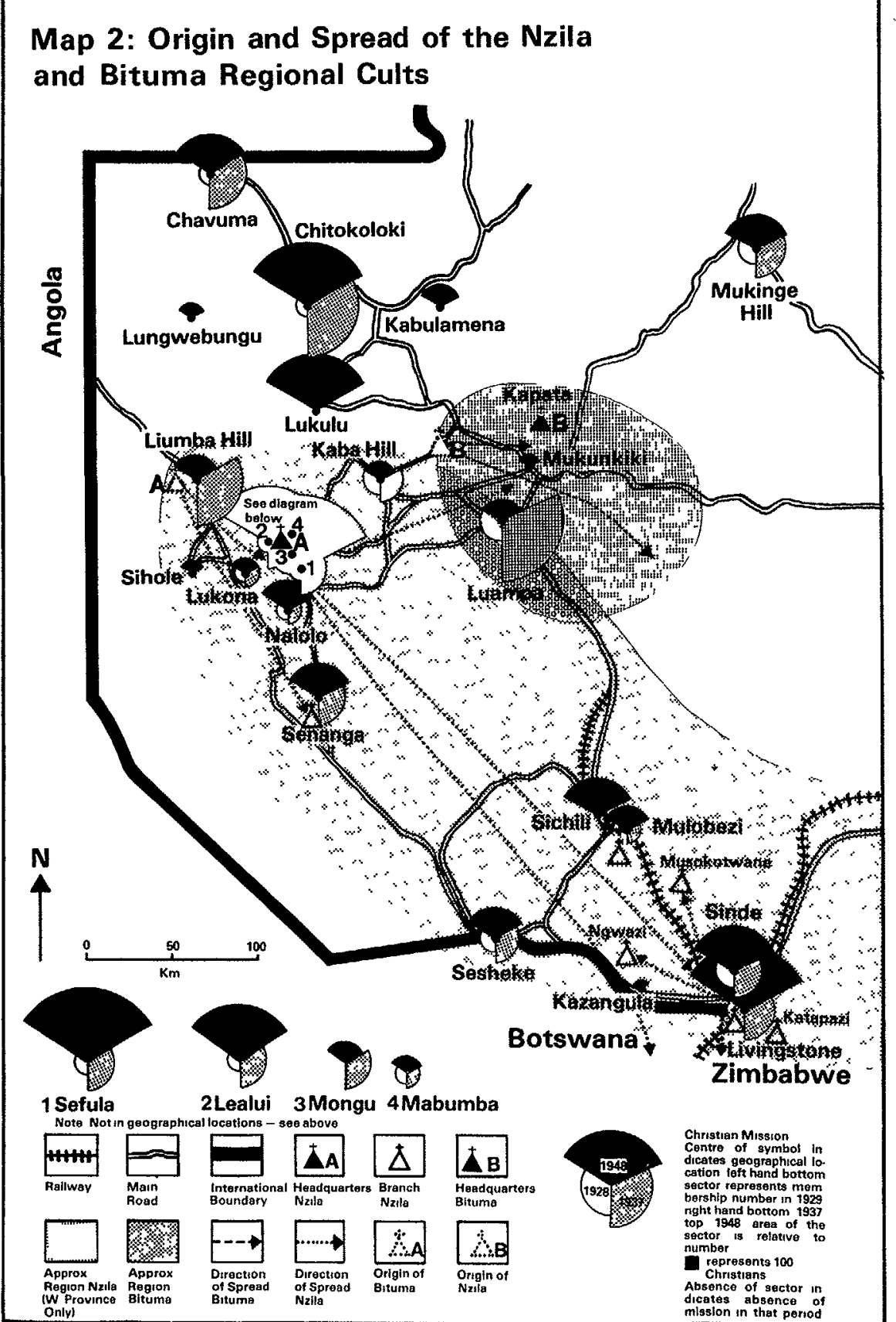

168 communications in general. The factional nature of the non-regional cults of affliction is partly explicable in this light. Similar problems play a much smaller role in densely populated areas, and a fortiori in towns.

More important perhaps, the demographic differences reveal a socialstructural difference between the situation of the typical Bituma adept in comparison with the typical Nzila adept. Bituma caters for a stagnated peasantry whose experience with urban living may be considerable (due to labour migration), but whose prime identification and source of economic and social security is the village. Modern institutions, and particularly formal, bureaucratic organizations in the political and economic sphere do penetrate from the metropolitan and national centres into the peripheral village scene, and determine the villagers' lives to an ever increasing extent. But these institutions and organizations, with physical outlets at the district centres mainly, are seldom visible at the village scene. Their impact on rural life does not imply that the villagers frequently participate in them or identify with them-quite the contrary. Debarred from substantial economic and political participation in the wider national context, the people in the Bituma region see themselves primarily as part of an economic and political order whose major concerns and transactions refer to local, largely pre-capitalist, historical structures. Bureaucratic organizations set, from a distance, the narrow confines for the local social process but do not play a prominent role in the participants' subjective life-world. And it is primarily from the latter that we can hope to expect a solution to the problem of differential adoption of religious forms - that is, if we agree to view religion mainly as an interpretative and legitimating structure.

The social-structural situation that is typical of the Bituma region, does obtain in parts of the Nzila region as well. But in the latter's centres of gravity (Mongu, Livingstone-Mulobezi) the structural context is very different. Here people live in an urban or peri-urban environment, where their life to a large extent consists of participation in economic and political formal, bureaucratic organizations: civil service, industrial and commercial enterprises, schools, medical services, churches, political parties, recreational associations, etc. Understanding of, and identification with, complex patterns of formal task definition and bureaucratically legitimated authority based on legal rules, are essential for both psychological comfort and for economic survival in town and in the peri-urban and rural extensions of urban-based formal organizations. Parkin (1966) has emphasized the potential of urban voluntary organisations to become mechanisms of adaptation to the organizational structure of modern urban life. Nzila is likely to play a role in this respect. But what is more important in the context of the present argument, is that Nzlla's being embedded, from the 1940's on, in a general urban organizational environment, did provide, in the perception of Nzila's potential patients and adepts, obvious organizational models and patterns of bureaucratic legitimation by reference to which this cult could successfully make the transition from direct to routinized charisma. 
Whilst no doubt providing a solution for some of the problems engendered in its adepts by their confrontation with modern urban organizational structures, Nzila copied an organizational model derived from this very structure (and therefore recognizable, and acceptable, to its adepts). This appears to have been an important factor in Nzila's development into a successful regional cult.

The knowledge of such models and patterns was surely available in the Bituma region as well. But there such a formal organizational structure did not correspond with the peasants' subjective reality: the organizational micro-structure of their rural society. Nzila developed a regional organizational structure borrowed from and commensurate with the urban society by which it was surrounded. Bituma, after attempts towards regional organization, to a large extent lapsed back into a fragmented, factionalized organizational structure which is not only typical of the pre-existing nonregional cults of affliction, but which is also (in ways I cannot elaborate on here) in line with the fragmented economic and political structure of Nkoya village society.

I am not suggesting, though, that the structure of this rural society was entirely incompatible with formal, interlocal religious organization. Christian missions throughout Western Zambia demonstrate that such religious organizations are viable provided they receive ample political and logistic backing from national and metropolitan centres (a condition obviously not met in the case of Bituma). Missions are important for an understanding of the development of the regional cults in several other respects. They were among the few formal, bureaucratic organizations that were visibly present in the rural areas. In this way they introduced the rural population to a pattern of social organization prevailing in urban contexts. In addition the missions contributed to the ideological shift towards greater prominence of the High God, among the general population of Western Zambia.

Both Simbinga and Chana were exposed to local missions. But whereas Nzila subsequently spread in an area that was very heavily missionized, and where Christianity grew rapidly in the 1940's, Bituma spread in an area where missionary activity was very limited and in fact declining in the 1940's (map 2). ${ }^{13}$ By consequence, Nzila could benefit much more than Bituma from the missions' instilling, in the minds of potential adepts, such attitudes and organizational models as are conducive to a regional cult organization.

The relation between Nzila and Christianity was and is extremely tolerant

13 Map 2 gives, inter alia, an overview of the size, growth and distribution of Christianity in Western Zambia between the years 1929 and 1948, the crucial period for the emergence and early development of Nzila and Bituma. Basic figures were derived from: Northern Rhodesia, 1929, 1937, 1948.
Muntemba points out (1972: 12f) that Nzila has developed a considerable degree of symbiosis with Christian churches. Many of the adepts and patients are Christians, even some Nzila leaders are church leaders, and Chana has remained a member of the Seventh Day Adventist Church throughout his life. In the early stages of Bituma, on the contrary, Simbinga denounced membership of Christian churches, claiming that "now we have our own church". In later years this antagonism made way for tolerance and at present the cult is indifferent with regard to its patients' and adepts' religious affiliations.

A final point of difference between Nzila and Bituma revolves around the role that ethnicity has played in the development of either cult. Belonging to the Luvale ethnic group, Chana was an Angolan immigrant: one of the many thousands that have moved into the rural areas throughout Western Zambia since the 1920's (Clay 1945; Colson 1970). Chana utilized Luvale ethnic identity to get his cult off the ground in the first instance. Nzila's spread closely followed the penetration of Angolan immigrants in the area. However,

"by the later 1940's the movement had spread to other parts of the Western Province and drew adherents not only from the Luvale (...) but from the Lozi as well as other groups in the Province."' (Muntemba 1972:3)

The mono-ethnic element now appears no longer to play a role in Nzila.

By contrast, Simbinga could hardly rely on ethnic support. He belonged to the Mbunda ethnic group and was an Angolan immigrant like Chana. Unable to find recognition and support among his own people, at the time of his first appearance as a prophet, he turned to the Nkoya who have lived in Kaoma district at least since the last century. The majority of Bituma leaders that Simbinga initiated were Nkoya, Kapata being a notable exception. Instead of utilizing the enormous numerical potential of the Angolan immigrants, as Chana did, Simbinga thus concentrated on a relatively small ethnic group tied to a rather small territory that was increasingly encroached upon by Angolan immigrants, and with no substantial portion of stabilized urbanites among their number. Concentration on the Nkoya is likely to have contributed to the lack of expansion of Bituma. On the other hand, this very concentration made the Bituma cult into a distinctive cultural feature, a sign of Nkoya identity especially among Nkoya migrants in town. Before that time, only the mayımbwe non-regional cult had played that role to some extent.

Ethnicity, or rather local nvalry in an ethnic disguise, also played a role in the later decline of Bituma as a regional cult. The central and eastern parts of Kaoma district form two subdivisions " Nkoya proper" and "Mashasha") of the Nkoya ethnic group. Despite frequent intermarriage and intra-rural residential mobility between these two subdivisions, they 
display mutual antagonism based on a different politıcal, administrative and mission history. Each subdivision has its own senior chief. There are close kin relations between the Mashasha chief and Bituma leaders in the eastern subdivision, and the same is true of the chief in the central subdivision and the Bituma leaders there. The latterday cleavage between Simbinga and Kapata, even though both are non-Nkoya, coincided with one between ethnically-articulated power-blocks in the political structure of the district.

The preceding argument suggests systematic reasons why, with the decline of Bituma, Kapata could yet retain around him some remnants of the cult's regional organization. Density of population is much higher in the central part of Kaoma district (and particularly north-west of Maoma township, where Kapata's village is situated) than it is in the eastern part. Moreover the large Mangango mission (created in the early 1950's some 15 kilometres north-west of the earlier Mukunkiki site), the annexed hospital, and the secular enterprise it has generated in the way of trading firms and cooperatives, along with the proximity of Kaoma and of Luampa mission, create a structural and ideological milieu more favourable for an interlocal regional cult, than exists in the eastern part of the district.

\section{Conclusion}

My analysis of two recent Zambian regional cults is based, to a large extent, on far from complete, oral-historical data. Even though I can analyse these data against the background of acquaintance with the area, with the nonregional cults of affliction from which the regional cults in question emerged and with main trends in the religious history of Central Africa in general, the whole argument remains too tentative to approach a theory of the dynamics of regional cults. However, my argument does lead to a few comparative generalizations.

Every regional cult seems to face a dual problem. On the one hand, it has to develop a distinct, specific cultic idiom (in terms of both ideology and ritual). On the other hand, it requires a formal organizational structure which shares out ritual authority sufficiently widely among officials to enable them to cover an entire region, whilst retaining these officials within an authority-legitimizing structure of such effectiveness as to prevent them from either breaking away from the cult or, within its organization, pursuing too deviant an idiom. The dialectical process in which solutions for this problem are worked out with varying success, is determined by number of factors. In addition to personality traits and interpersonal relationships of the personnel involved, crucial factors appear to be of two kinds. First, the specific nature of a cult's organizational devices to a large extent determines its chances of survival as a regional cult. Secondly, these organizational devices are partly determined by the structural characteristics which obtain in the geographical area that the cult is to transform into a region. My argument suggests the importance, among these structural characteristics of the region, of demographic patterns and of the occurrence, besides the cult in question, of other religious and non-religious, formal, interlocal organizations. However, only application to more, and better data from other parts of the world can throw light on the validity of these suggestions.

\section{References:}

\section{Carter, M.}

1972 Origin and Diffusion of Central-African Cults of Affliction. Conference on the History of Central-African Religious Systems, University of Zambia, Lusaka. Manuscript.

\section{Clay G.C.R.}

1966 History of the Mankoya District. Lusaka: Rhodes -Livingstone Institute Communication 4.

Colson E.

1970 The Assimilation of Aliens among Zambian Tonga. In From Tribe to Nation in Africa. R. Cohen and J. Middleton, Eds. Scranton: Chandler Publishing Co. pp. 35-54.

Davies D.H.

1971 Zambia in Maps. London:Athlone Press.

Doke C.M.

1931 The Lambas of Northern Rhodesia. London: George G. Harrap and Co

Gluckman M.

1943 Notes on the Social Background of Barotse Music. In African Music.

A.M. Jones, Ed. Livingstone: Rhodes-Livingstone Museum.

1951 The Lozi of Barotseland N.W. Rhodesia. In Seven Tribes of Central Africa. E. Colson and M. Gluckman, Eds. Manchester: Manchester University Press. pp. 1-93.

Ikacana N.S.

1971 Litaba za Makwanga. Lusaka: Neczam. (Reprint of 1952 edition)

Kolb W.L.

1964 Cult. In A Dictionary of the Social Sciences J. Gould and W. L. Kolb, Eds. New York: Glencoe. The Free Press.

McCulloch, M.

1951 The Southern Lunda and Related People. Ethnographic Survey of Africa West Central Africa, I, London: Oxford University Press for International African Institute.

Merle Davis, J.et al

1933 Modern Industry and the African. London: Macmillan.

Muntemba, M.

1972 Zambia Nzila sect and Christian Churches in the Livingstone Area.Conference 
on the History of Central-African Religious Systems, University of Zambia, Lusaka. Manuscript.

\section{Northern Rhodesia}

1929 Blue Book for the Year Ended 31st December 1929. Livingstone.

1937 Blue Book for the Year Ended 31st December 1937. Lusaka.

1948 Blue Book for the Year Ended 31st December 1948. Lusaka.

O'Dea T.F.

1968 Sects and Cults. In International Encyclopaedia of the Social Sciences. New York.

\section{Parkin D.}

1966 Voluntary Associations as Institutions of Adaptation, Man. 1: 90-94

Ranger T.O.

1972 Report on the Proceedings of the Conference (on the History of CentralAfrican Religious Systems). African Religious Research 2: 6-35.

1973 Review Article: Magic and the Millenium. African Religion Research 3: 7-33

\section{Reynolds B.}

1963 Magic, Divination and Witchcraft among the Barotse of Northern Rhodesia London: Chatto and Windus.

\section{Shorter A.}

1972 Symbolism, Ritual and History: an Examination of the Work of Victor Turner. In The Historical Study of African Religion. T.O. Rangęr and I. Kimambo, Eds. London. pp.139-149.

\section{Stefaniszyn B.}

1964 Ritual and Social Life of the Ambo of Northern Rhodesia. London: Oxford University Press.

\section{Symon S.A.}

1959 Notes on the Preparation and Uses of African Medicine in the Mankoya

District, Northern Rhodesia. Rhodes-Livingstone Communication 15. pp. 21-77.

Turner V.W.

1952 The Lozi Peoples of North-West Rhodesia. London: International African Instutute.

1957 Schism and Continuity in an African Society: A Study of Ndembu Village Life. Manchester: Manchester University Press.

1962 Chihamba the White Spirit. Rhodes-Livingstone Paper 31. Manchester: Manchester University Press.

1968 The Drums of Affliction. Oxford: Oxford University Press for the International African Institute.

Van Binsbergen, W.M.J.

1972a Bituma: Preliminary Notes on a Possession Healing Cult among the Nkoya. Conference on the History of Central-African Religious Systems. University of Zambia, Lusaka. Manuscript. 1972b Possession and Mediumship in Zambia: Towards a Comparative Approach. Conference on the History of Central-African Religious Systems. University of Zambia, Lusaka. Manuscript.

1975 Ethnicity as a Dependent Variable: the 'Nkoya' Ethnic Identity and InterEthnic Relations in Zambia. 34th Annual Conference, Society for Applied Anthropology. Amsterdam. Manuscript. African Social Research, forthcoming. 1976a Ritual, Class and Urban-Rural Relations. Cultures et Developpement. 8 : 195-218.

1976b Social Change and Intergenerational Conflict among the Nkoya of Zambia. Cultures et Developpement. 8.

1976c Law in the Context of Nkoya Society. In Law and the Family in Modern Africa. S.A. Roberts, Ed. The Hague: (In press)

1976d The Dynamics of Religious Change in Western Zambia. Ufahamu 6: 69-87. 1977a Explorations into the History and Sociology of Territorial Cults in Zambia. In Guardians of the Land: Essays in Central-African Territorial Cults. J.M. Schoffeleers, Ed. Gwelo: Mambo Press (In Press).

1977b Religious Innovation and Political Conflict in Zambia: A Contribution to the Interpretation of the Lumpa Rising. In Religious Innovation in Modern African Society. R. Buijtenhuijs and W.M.J. Van Binsbergen, Eds. African Perspectives, Leiden: Afrika-Studiecentrum. In Press.

\section{Weber M}

1969 The Theory of Social and Economic Organization. Glencoe: The Free Press.

Werbner R.P.

1971 Symbolic Dialogue and Personal Transactions among the Kalanga and Ndembu. Ethnology 10: 311-328

1972 Sin, Blame and Ritual Mediation. In The Allocation of Responsibility. M. Gluckman, Ed. Manchester: Manchester University Press. pp. 227-235.

Wilson, B.R.

1975 Magic and the Millenium. Frogmore: Paladin/Granada Publishing Limited. Reprint of 1973 edition.

(C) Wim M J Van Binsbergen 1977 